\title{
Daganatos betegekben kialakult másodlagos nyiroködéma ellátása
}

\author{
Wenczl Enikő dr. \\ Egyesített Szent István és Szent László Kórház, II. Krónikus Belgyógyászati Osztály, Lymphoedema Részleg, \\ Lymphoedema és Bőrgyógyászati Szakrendelés, Budapest
}

\begin{abstract}
A daganatos betegek számának emelkedésével és az onkológiai kezelések hatékonyságának növekedésével egyre gyakrabban találkozunk másodlagosan kialakult nyiroködémával. Ezért a nyiroködéma kezelése az onkológiai betegek gondozásának része. A nyiroködéma kezelésének alapja daganatos betegekben a komplex ödémamentesítő kezelés, amelyet bele kell ágyazni a beteg átfogó orvosi ellátásába és mindig egyénre szabva kell meghatározni. A kezelés eredménye függ az orvos és a gyógytornász nyiroködéma-kezelésben való jártasságától, a betegcompliance-től, a daganat viselkedésétől és a kísérő betegségektôl. A nyiroködéma krónikus betegség, élethosszig tartó gondozást, kezelést igényel. Az ellátás javítása érdekében fontos a betegek felvilágosítása a nyiroködéma kockázatát illetően és az erre vonatkozó helyes életmóddal kapcsolatosan (például testsúlykontroll); törekedni kellene a diagnózis korai felállítására. A palliatív ellátásba is lényeges lenne beépíteni a nyiroködéma-kezelést. Időben elkezdett terápiával elkerülhetők a szövődmények, az egészségügyi kiadások csökkenthetők és a beteg számára jobb életminőség biztosítható. Orv. Hetil., 2016, 157(13), 488-494.
\end{abstract}

Kulcsszavak: nyiroködéma, onkológia, malignus nyiroködéma, komplex ödémamentesítő kezelés, palliatív ellátás

\section{Management of secondary lymphedema in patients with cancer}

Due to the increased number of cancer patients and the progress in cancer treatment, there are more cases with cancer-related lymphedema. Lymphedema treatment became part of oncological patients' care. Basic therapy for lymphedema is the complex decongestive therapy, which should be embedded into the patient's comprehensive medical care and should always be determined individually. Results of therapy are influenced by the experience of the doctor and the physiotherapist in lymphedema care, patient's complience, tumor behavior and the accompanying diseases. Lymphedema is a chronic disease, requires lifelong follow-up and treatment. For prevention and better care, it would be important to inform patients about lymphedema risk and appropriate life-style (e.g. weight control) preoperatively and during oncological follow-up. Early diagnosis is important. Lymphedema treatment should be integrated into palliative programmes. If therapy is started in time, complications may be avoided, healthcare costs may be reduced and better quality of life may be achieved.

Keywords: lymphedema, oncology, malignant lymphedema, complex decongestive therapy, palliative care

Wenczl, E. [Management of secondary lymphedema in patients with cancer]. Orv. Hetil., 2016, 157(13), $488-494$.

(Beérkezett: 2016. január 11.; elfogadva: 2016. február 4.)

\section{Rövidítés}

KÖK = komplex ödémamentesítő kezelés

Ritkán ismerjük fel, vesszük komolyan és kezeljük szakszerüen a nyiroködémát, pedig a várható élettartam emelkedésével megnőtt a nyiroködémás betegek száma. $\mathrm{Az}$ életkor elörehaladtával ugyanis fokozatosan csökken a nyirokszállítás kapacitása és egyre gyakoribbak a nyirok- ödéma rizikófaktorai. A különféle daganatok előfordulása is emelkedik, és az onkológiai kezeléseknek köszönhetően hosszabb a túlélés, gyakoribb a gyógyulás. Mindezek következtében gyakrabban találkozunk daganatos betegekben másodlagosan kialakult végtagi, törzsi, arcon lévő és genitális nyiroködémával. Így vált vagy kellene, hogy váljon a nyiroködéma kezelése az onkológiai betegek gondozásának részévé. 


\section{A szekunder nyiroködéma okai daganatos betegekben}

Nyiroködéma tumoros betegekben a nyirokelfolyás akadályozottsága miatt alakul ki. A nyiroködéma kialakulása két okból történhet: 1. a daganat kezelése során végzett orvosi beavatkozások (mûtét, nyirokcsomó-eltávolítás, irradiáció, kemoterápia - 1. ábra) következtében, 2. közvetlenül maga a daganat vagy annak tovaterjedése, kiújulása (nyirokér mechanikus nyomása a tumor által, nyirokér-invázió, nyirokcsomóáttét - 2. ábra) által. A iatrogén okból kialakult nyiroködéma a gyakoribb, és mindig azt a régiót érinti, amelynek nyirokelfolyása akadályozottá válik az orvosi beavatkozás következtében vagy közvetlenül a daganat vagy áttét miatt.

A leggyakoribb nyiroködémát okozó daganatok a mellrák, a nőgyógyászati tumorok (cervix-, vulva-, endometrium-, ovariumcarcinoma), az urológiai daganatok (prosztata-, here-, húgyhólyag-, pénisztumorok), az enteralis tumorok (rectum-, coloncarcinoma), a bőrgyógyászati tumorok (melanoma malignum) és a hematológiai tumorok (Hodgkin-, non-Hodgkin-lymphomák). A nyiroködéma kialakulásának gyakorisága daganatkezelés után számottevő. Egy prospektív, 160 betegen végzett vizsgálat szerint mellmegtartó mütét esetén a nyiroködéma kialakulásának gyakorisága a mellen $35-48 \%$ volt axillaris blokkdissectio után, míg sentinel-nyirokcsomó eltávolítása után 23\% [1]. Nyolcszázkettő, nőgyógyászati tumorkezelésen átesett nőbeteg kérdőíves vizsgálata alapján 25\%-ban alakult ki panaszt okozó alsó végtagi ödéma, de a nyiroködéma diagnózisa csak az érintett betegek 40\%-ában lett felállítva [2]. A diagnosztizált esetekben a nyiroködéma gyakorisága vulvacarcinoma kezelése után volt a legnagyobb, 36\%, cervixcarcinoma kezelése után $12 \%$, és ovariumcarcinoma terápiája után volt a legkisebb, $5 \%$.

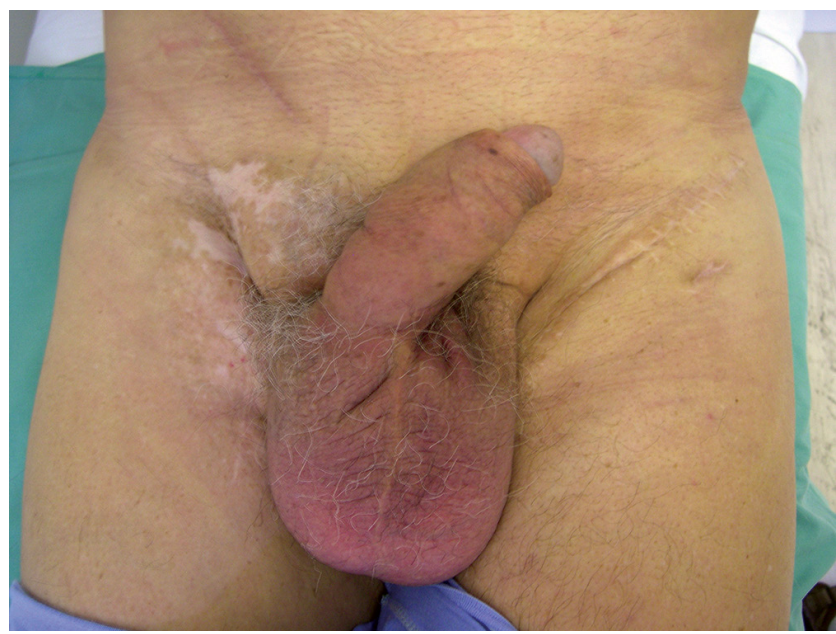

1. ábra

Jobb lábszáron melanoma malignum-eltávolítás, jobb oldali inguinalis blokkdissectio és irradiáció okozta genitális nyiroködéma

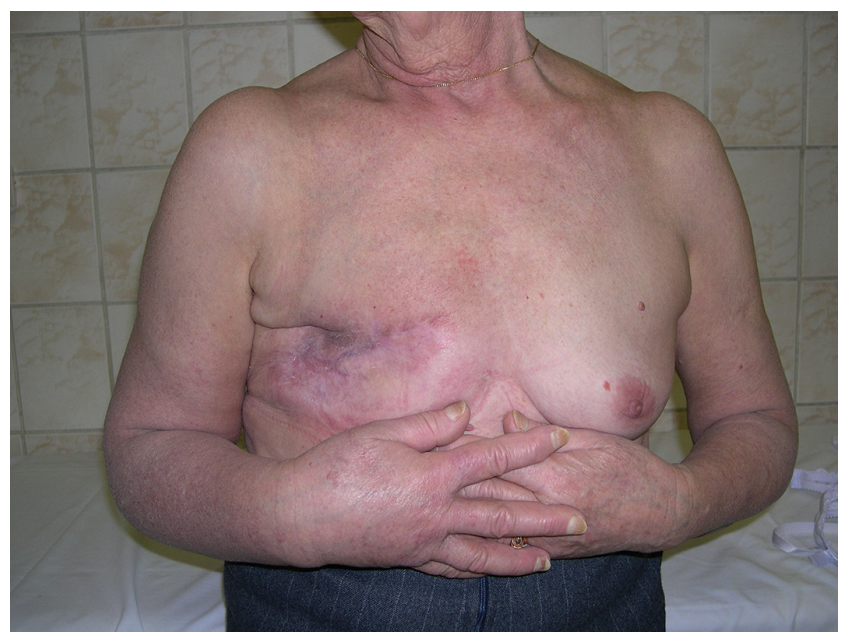

2. ábra

Jobb mellet abláló meglévő tumor és hónalji nyirokcsomóáttétek okozta jobb felső végtagi nyiroködéma

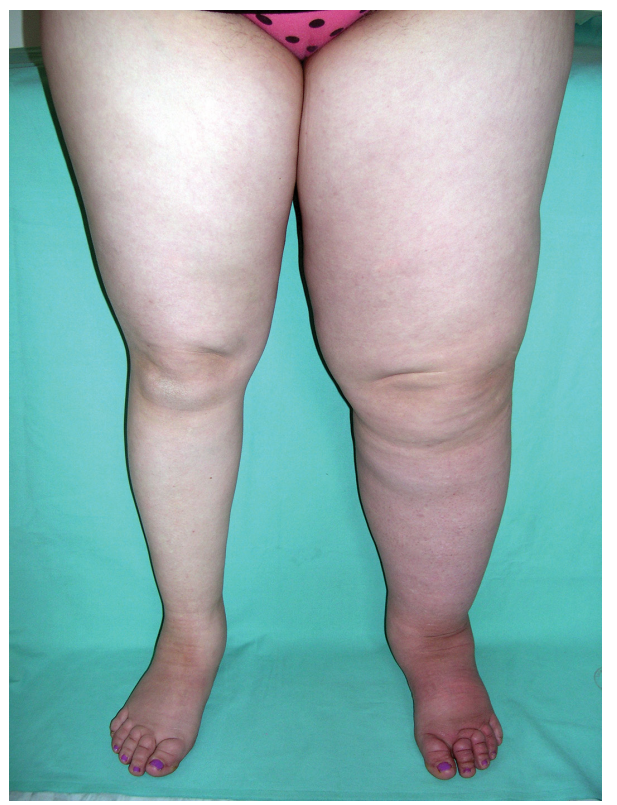

3. ábra

| Wertheim-mútét után kialakult bal alsó végtagi nyiroködéma

\section{Klinikai tünetek}

A tumoros betegekben kialakult nyiroködéma tünetei megegyeznek az egyéb okból kialakult nyiroködéma tüneteivel: ödéma, amely kezdetben az ujjbenyomatot tartja, később már alig vagy nem tartja, narancsbőrtünet, Stemmer- (ujjráncteszt) pozitivitás az érintett területeken (például ujjakon, háton, hónaljban, combon, csípőn), kézfej-lábfej cipószerü duzzanata, ujjak tövében csecsemőráncok megjelenése, lymphangiectasiák (3. és 4. ábra). A beteg panaszolhatja a végtag nehézzé válását, ami a végtag súlyának fokozódásából adódik. További panasz lehet a bőr feszülése, esetenként fájdalma vagy az érintett ízület hajlékonyságának csökkenése. A kar nyiroködémája esetén nehezen fér bele a kar a ruha ujjába, a beteg nem tudja fel- vagy lehúzni a megszokott gyưrüt 


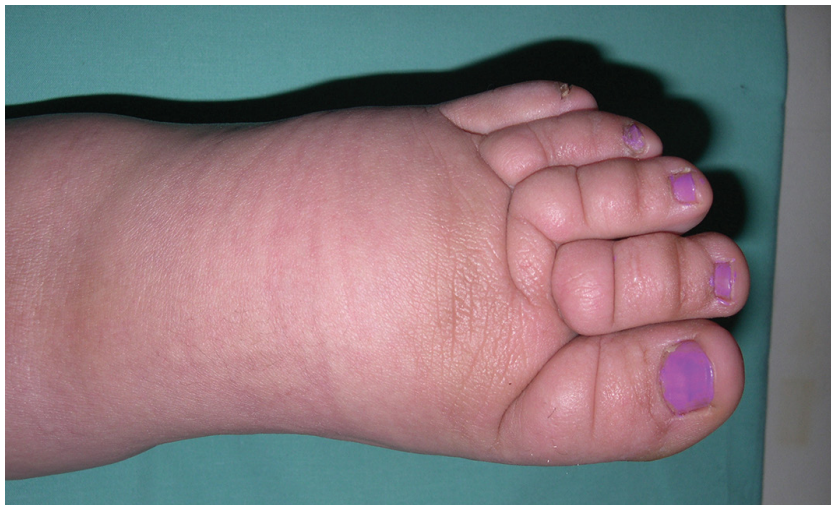

4. ábra

Wertheim-mútét után kialakult bal alsó végtagi nyiroködéma, ujjak Stemmer-pozitívak, lábhát cipószerú

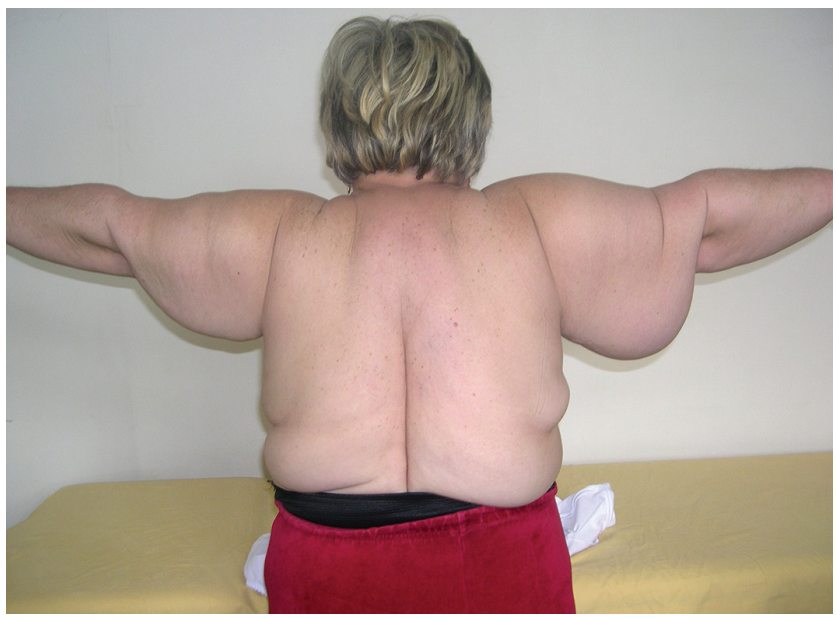

5. ábra

Jobb oldali mellablatio és axillaris blokkdissectio után jobb karon szekunder nyiroködéma, az állapotot a felkarokat érintó lipoedema rontja

vagy felvenni a korábban passzoló órát vagy karkötőt. Alsó végtagi érintettség esetén nem fér bele a lába a cipőbe, a nadrágja feszül az érintett végtagon, és nehézzé válik a járás. A tünetek tehát befolyásolhatják a hétköznapi életvitelt, a szabadidő eltöltését és a munkaképességet is. A tünetek megjelenhetnek az orvosi beavatkozás után néhány nappal, de akár több évvel később is. Daganatkezelés után tehát mindig fennáll a szekunder nyiroködéma kialakulásának rizikója.

\section{Kockázati tényezők}

A nyiroködéma kialakulását és súlyosságát számos külső és belső tényező befolyásolja (1. táblázat). A külső tényezők a következők lehetnek: mútét radikalitása (például eltávolított nyirokcsomók száma), mútéti vagy későbbi szövődmények (például seroma, sebfertőzés, cellulitis), irradiáció vagy kemoterápia [3]. A belső tényezők közé tartoznak: a tumor stádiuma és számos egyéb nyiroködémára hajlamosító kísérő betegség, mint obesitas, lipoedema, anyagcsere-betegségek, immobilizáció, szív-,
1. táblázat | A nyiroködéma kialakulását és súlyosságát befolyásoló tényezők

\begin{tabular}{l}
\hline Külső tényezők \\
Műtét radikalitása \\
Mütéti szövődmények \\
Irradiáció \\
Kemoterápia \\
\hline Belső tényezők \\
Tumor stádiuma \\
Obesitas \\
Lipoedema \\
Anyagcsere-betegségek \\
Szív-, vese-, májelégtelenség \\
Krónikus tüdőbetegség \\
\hline
\end{tabular}

vese-, májelégtelenség, krónikus tüdőbetegség stb. (5. ábra). Számos vizsgálat igazolta, hogy az obesitas megnöveli a nyiroködéma gyakoriságát daganatkezelés után $[4,5]$. Bár az obesitas és a nyiroködéma kialakulásának rizikója közötti dózis-hatás kapcsolat még nem világos, de létezik már evidencia, amely alátámasztja, hogy testsúlycsökkentés hatására mérséklődik a nyiroködéma [6]. Melldaganat miatt kezelt betegekben kimutatták, hogy a fizikai aktivitás nem növeli a nyiroködéma kialakulásának rizikóját, és javasolt nagyon alacsony intenzitással kezdeni és fokozatosan emelni a terhelést a tünetek megjelenését figyelve $[7,8]$.

\section{Benignus és malignus nyiroködéma}

Ritkán a daganat első jele lehet a nyiroködéma megjelenése, ekkor tumorkutatást kell indítani. A daganat miatt kialakult nyiroködémás betegek gondozása során elengedhetetlen az onkológiai gondozás nyomon követése. A tumorrecidíva kialakulásának ugyanakkor számos, a nyiroködéma-gondozás során is észlelhető jele lehet, amely esetenként megelőzheti a képalkotó eljárásokkal kimutatható progressziót (2. táblázat). Ilyen jelek a nyiroködéma területén fellépő konstans, erős fájdalom; vénás vagy vöröses rajzolat megjelenése; terápiarezisztenssé váló, gyakran centrális túlsúlyú nyiroködéma; ne-

2. táblázat |A malignus nyiroködéma klinikai tünetei

Konstans, erôs fájdalom a nyiroködémás végtagon

Vöröses, vénás rajzolat

Terápiarezisztens nyiroködéma

Centrális túlsúlyú nyiroködéma

Neurológiai tünetek (paresis, plegia, érzészavar)

Csomók (bőrmetasztázisok)

Nem gyógyuló sebek (kifekélyesedő bőrmetasztázisok) 
urológiai tünetek (paresis, plegia, érzészavar) megjelenése; csomók (bőráttétek), nem gyógyuló sebek (kifekélyesedett bőráttétek) kialakulása (6. és 7. ábra). A tumorrecidíva megjelenésének ritka manifesztációja a carcinoma en cuirasse, magyarul páncélkarcinóma, amelyet a nyiroködéma által is érintett bőr progresszív, kiterjedt fibrosisa, sclerodermoid átalakulása jellemez (8. ábra). Leggyakrabban metasztatikus melltumor esetén írták le ezt a bőrmetasztázis-formát [9]. A tumorrecidíva kialakulása során megjelenő, jelen lévő vagy progrediáló nyiroködémát malignus nyiroködémának nevezzük. Szintén malignus nyiroködémáról beszélünk, ha egy meglévő primer tumor (amely lehet inoperábilis vagy még nem eltávolított) következtében észlelünk nyiroködémát. Minden egyéb esetben benignus nyiroködémáról van szó daganat miatt kezelt betegekben is.

\section{Terápia}

A nyiroködéma-kezelés alapja daganatos betegekben is a komplex ödémamentesítő kezelés (KÖK; angolul complex decongestive therapy). Még a kezelés megkezdése előtt elengedhetetlen a beteg alapos kivizsgálása és a kísérő betegségek kezelése, valamint annak megállapítása, hogy benignus vagy malignus nyiroködémáról van-e szó $[10,11]$. A KÖK-öt bele kell ágyazni a beteg átfogó orvosi ellátásába, hogy megelőzzük a mellékhatásokat. Az ödéma eredete ugyanis gyakran multifaktoriális. Bizonyos esetekben a KÖK-öt módosítani kell a beteg állapotának függvényében. Számos gyógyszer okozhat ödémát és súlyosbíthatja a meglévő nyiroködémát, így fontos a szedett gyógyszerek áttekintése ebből a szempontból [12].

A KÖK részei a manuális drenálás, a gondos bőrápolás, a kompressziós kezelés és a gyógytorna. A manuális drenálás egy finom masszázstechnika, amely mobilizálja a felgyülemlett nyirokfolyadékot a nyiroködéma által érintett régióból. Elöször a törzsön, majd a végtagon alakítja ki a károsodott vagy lezárt nyirokkeringésű régiót kikerülő, úgynevezett kollaterális nyirokkeringést. Hatására csökken a nyiroködéma, mérséklődik a fájdalom, és az emberi érintés a beteg számára pszichés támogatást is jelent, különösen palliatív kezelés esetén van ez utóbbinak nagy jelentősége. A bőrkezelés célja a bőr épségének megőrzése, a gombás és bakteriális fertőzések megelőzése. Általános bőrápolással kezdődik, amelyet szükség esetén fertőtlenítő, antimycoticus vagy helyi gyulladáscsökkentő kezeléssel egészítünk ki. A kompressziós kezelés a KÖK harmadik fontos része. A kompressziós kezelés módja változatos (többkomponensü fáslirendszerek, kompressziós gyógyharisnya, tépőzáras kompressziós eszközök, gépi kompressziós kezelés). Kiválasztásakor figyelembe vesszük a kísérő betegségeket, a pszichoszociális faktorokat, a kezelés célját és fázisát. Gyógytorna végzésével pedig aktiváljuk az izom és ízületi pumpákat, amelyek fontos ödémavédő mechanizmusok. Melldaganat miatt kialakult szekunder nyiroködé- más betegekben az intenzív kompressziós kezelés hatására 30-39\%-kal csökkent a nyiroködéma mértéke a karon, és manuális drenálással kiegészítve a kezelést további körülbelül 7\%-os csökkenés volt elérhető [13].

A kezelésnek két fázisát különítjük el: intenzív és fenntartó fázis. Az első intenzív kezelési fázis kórházi felvétel vagy ambuláns kezelés formájában is történhet. Az intenzív fázis fontos része a beteg felkészítése az otthoni kezelésre, amely a fenntartó kezelés alapja. A naponta végzett KÖK-ön túl a terápia további elemei lehetnek a diétás tanácsadás, a pszichoterápia, a relaxációs technikák, a hozzátartozók oktatása/házi ápolás megszervezése és az intenzív fázis végén a gyógyharisnya/ortopéd cipő méretvételi lehetőség biztosítása. A kezelő team tagjai: nyiroködéma-specialista orvos, nyiroködéma-kezelésben jártas gyógytornász és nővér, ezenkívül onkológus, szükség esetén ortopéd orvos, belgyógyász, pszichoterapeuta, ortopéd cipész, szociális munkás és dietetikus. A kezelést nyiroködéma-kezelésben jártas szakorvos indikálja és a gyógytornásszal, nővérrel együtt határozzák meg az adott beteg esetében a kezelés elemeit [14]. Az intenzív fázis végére a betegnek tudnia kell a segédeszközöket szakszerúen használni, az önkezelést, gyógytornát rutinosan végezni és a bőrét megfelelően ápolni. Amennyiben a beteg maga erre nem képes, hozzátartozó vagy házi ápoló betanítására kerül sor. A betegtájékoztatásnak ki kell térni a szövődmények kérdésére is. Fontos, hogy fel tudja ismerni a beteg, mely tünetek jelentkezésekor szükséges kezelőorvosát soron kívül felkeresnie.

Malignus nyiroködéma fennállásakor mindig az onkológiai kezelést kell elsődlegesnek tekinteni, az ödémamentesítő kezelés csak ezt kiegészítően jön szóba. Ha az onkológiai kezelés palliatív célból történik, palliatív ödémamentesítésről beszélünk, amely szükség esetén kiegészítendő palliatív sebkezeléssel és fájdalomcsillapítással. Számos szerző érvel amellett, hogy a manuális drenálás végzése nem kontraindikált áttétes tumor fennállása esetén, de ilyen esetben a manuális drenálást az adott helyzethez kell adaptálni [15-19]. Elméletileg ugyan a nyirokkollektorokban már jelen lévő tumorthrombusokat befolyásolhatja a manuális drenálás vagy a kompresszió, de a nemzetközi konszenzus is elismerte a KÖK alkalmazásának palliatív előnyeit aktív tumor fennállásakor [11]. A cél ebben az esetben nem a nyiroködéma minél nagyobb fokú csökkentése, hanem az életminőség javítása $[16,20]$. A kezelést a kezelőteamnek a betegre szabva kell meghatározni, a standard kezelést módosítva. Ilyen módosítások lehetnek: a tumor vagy áttét által érintett bőrterületek elkerülése a manuális drenálás során; a standard kezeléshez képest alacsonyabb nyomással felhelyezett fásli; a kifekélyesedő tumor sebellátása; plegiás végtagra adaptált gyógytorna stb. Pinell és mtsai által végzett klinikai vizsgálat szerint a KÖK lokoregionális tumor fennállása esetén is ugyanolyan hatékonynak bizonyult, bár hosszabb kezelési időre volt ehhez szükség, mint tumormentes szekunder nyiroködémás betegekben [18]. 


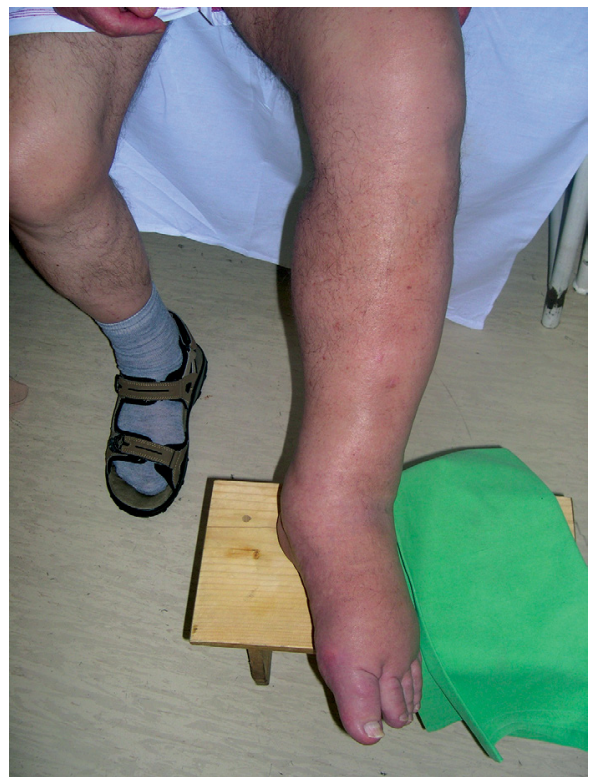

6. ábra

Inoperábilis coloncarcinoma okozta bal alsó végtagi malignus nyiroködéma, peroneus paresis

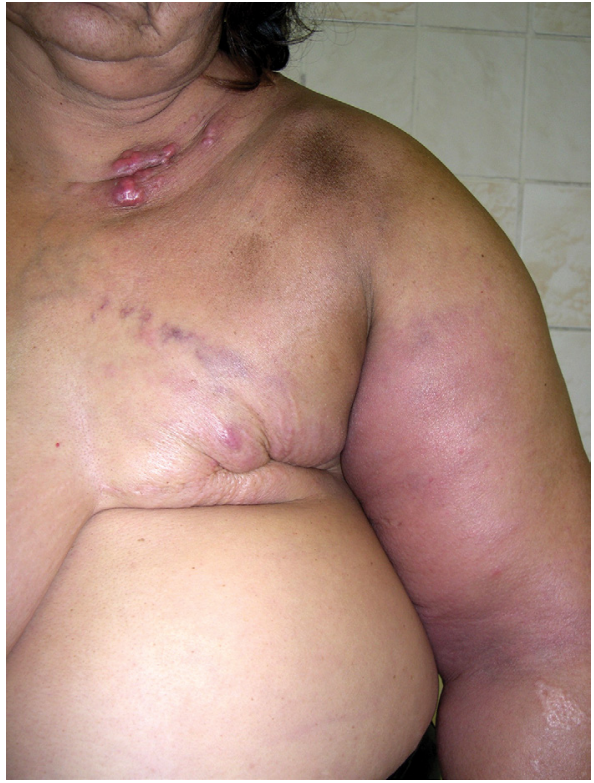

7. ábra

Malignus nyiroködéma bal karon bal oldali mellablatio és axillaris blokkdissectio után cutan metasztázisokkal, vénás rajzolat a mellkasfalon

Míg benignus nyiroködémában vízhajtó adása nem javasolt, malignus nyiroködéma esetén a KÖK-öt gyakran ki kell egészíteni diuretikumokkal [10].

A KÖK-öt tehát mindig egyénre szabottan kell meghatározni. Fontos a szoros együttmúködés a teamtagok között, különösen malignus nyiroködéma fennállásakor végzett palliatív nyiroködéma-kezelés esetén. A kezelés eredménye függ az orvos és a gyógytornász nyiroködéma-kezelésben való jártasságától, a betegcomplience-tól, a daganat viselkedésétől és a kísérő betegségektől [21]. A nyiroködéma egy krónikus betegség, élethosszig tartó gondozást, kezelést igényel.

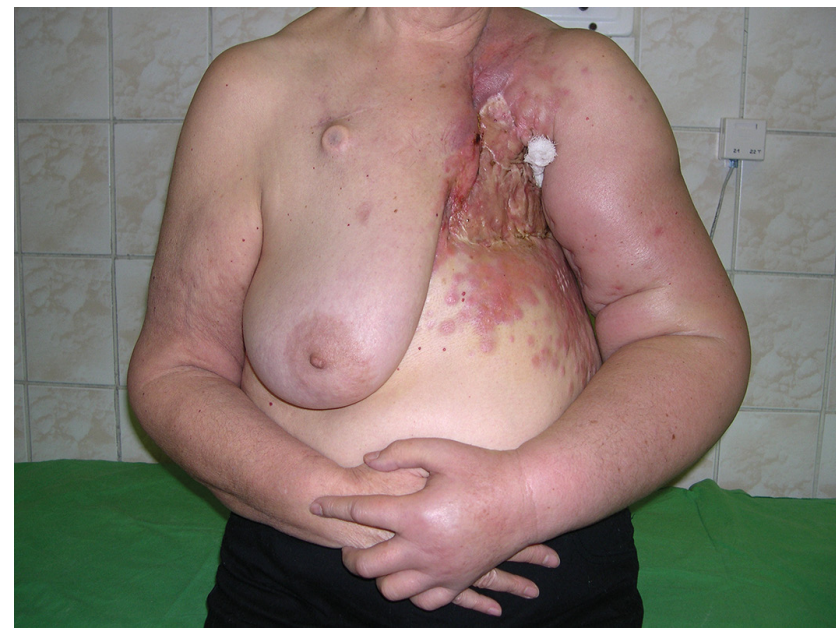

\begin{tabular}{l|l} 
8. ábra & Progrediáló melldaganat, carcinoma en cuirasse
\end{tabular}

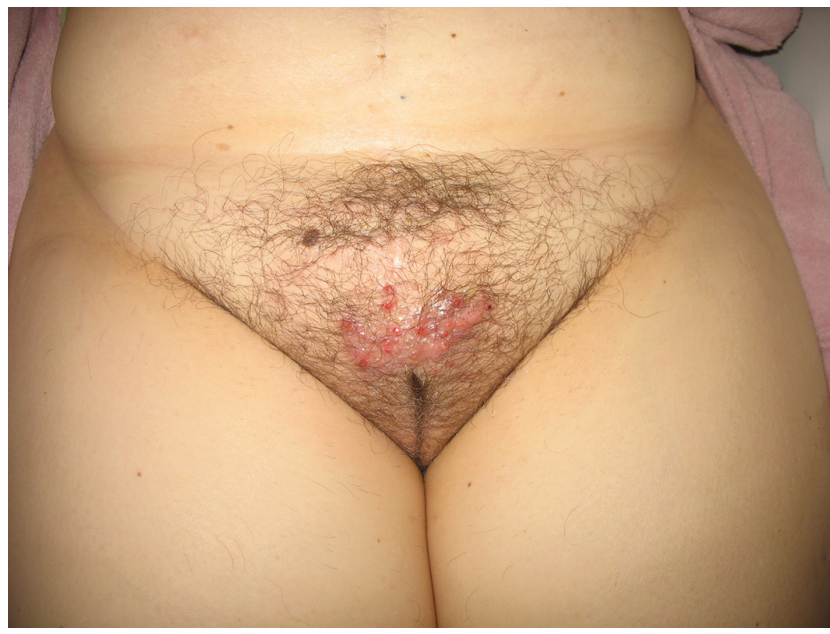

9. ábra

Wertheim-mútét után bal lábon és mons pubison szekunder nyiroködéma, mons pubison nyirokciszták, nyirokfisztulák, nyirokcsorgás

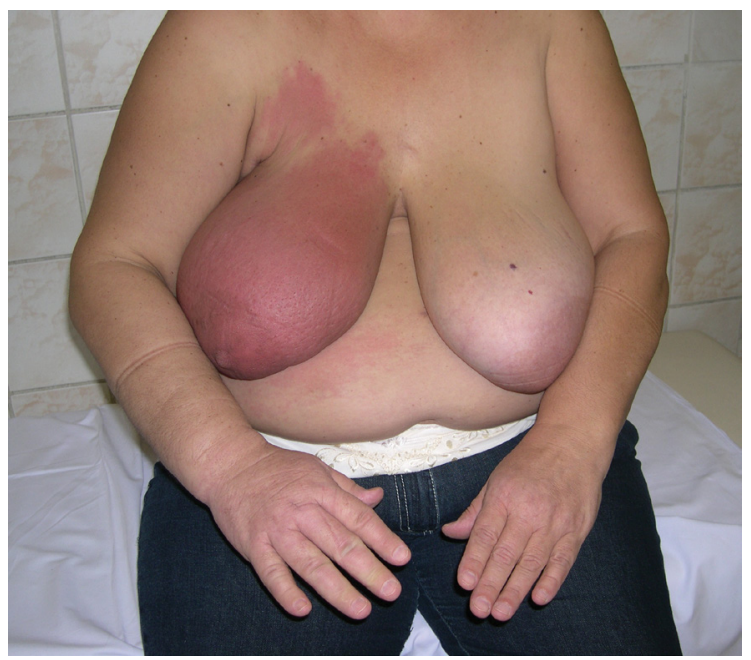

10. ábra

Jobb mellen szektorreszekció és axillaris blokkdissectio után szekunder nyiroködéma, jobb mellen szövődményként orbánc zajlik 


\section{Szövődmények}

A nyiroködéma általános szövődményei daganatos betegekben is kialakulhatnak. Leggyakrabban nyirokcsorgást észlelhetünk, amelynek hátterében nyirokciszták, nyirokfisztulák lehetnek (9. ábra). A nyirokcsorgás talaján eróziók, sebek alakulhatnak ki, amelyek baktériumok számára behatolási kapuk és fertőzések (folliculitis, cellulitis, orbánc, lymphangitis, fasciitis necrotisans) kialakulásához vezethetnek a nyiroködéma miatt immunszupprimált területen (10. ábra). Gombás bőrbetegségek kialakulása is gyakori. Ritka, de igen súlyos szövődmény a lymphangiosarcoma kialakulása [22]. A végtagok súlya is erősen megnövekedhet az ödéma miatt, ami funkcionális zavart, immobilizációt okozhat elsősorban a lábon. Gyakran a lábfej megnagyobbodása miatt ortopéd cipó készíttetésére is szükség lehet. A nyiroködéma évekig való fennállása során a bőr fibroscleroticus átalakuláson megy keresztül, zsírszövet-lerakódás történik és a hám megvastagodik. Ennek jelei a bőr tömötté válása, hyperkeratosis, papillomatosis megjelenése, végtag megvastagodása és legsúlyosabb esetben akár elephanthiasis kialakulása. A KÖK megelőzi, lassítja, visszafordíthatja ezeket a változásokat és segíti elkerülni a szövődményeket.

\section{Megelőzés}

A nyiroködéma megelőzésének egyik lehetősége a betegfelvilágosításon túl a korán elkezdett KÖK, mint szekunder prevenció $[23,24]$. Ezenkívül külföldön egyre nagyobb jelentőségűvé kezd válni az úgynevezett primer sebészi prevenció, amikor mikrosebészeti módszerrel lymphaticovenosus anasztomózisokat hoznak létre a nyirokcsomó-blokkdissectióval egyidejûleg, így áthidalják a sérült területet és biztosítják a nyirokelfolyás útját $[25,26]$. A nyiroködéma mikrosebészeti rekonstrukciójának egyéb lehetőségei (például microvascularis nyirokcsomó transzplantációja) is intenzív kutatás tárgyai.

\section{A hazai ellátás javításának lehetőségei}

Hazánkban a prevenció területén még sok a teendő. Az onkológiai centrumokban és a sebészeti ellátóhelyeken a nyiroködéma-terápia ritkán hozzáférhető. Fontos lenne a betegek preoperatív és onkológiai gondozása során történő felvilágosítás a nyiroködéma kockázatát illetően, és az erre vonatkozó helyes életmóddal kapcsolatosan. Külön fel kell hívni a figyelmet a testsúlykontrollra, hiszen az obesitas egy fontos rizikófaktor. A nagy rizikójú (például túlsúlyos, obes, nyirokcsomó-eltávolításon átesett, radioterápiában részesült) betegeket pedig tájékoztatni kellene a nyiroködéma-kezeléssel foglalkozó egészségügyi szolgáltatók elérhetőségéről. A szövődmények elkerülése érdekében a diagnózis korai felállítására kellene törekedni.

Több ellátóhely a nyiroködéma kezelésében jártas orvosi felügyelet nélkül múk ödik, pedig a KÖK-öt önálló- an gyógytornász vagy gyógymasszőr nem indikálhatja. A gyógytornászok nyiroködéma-kezelésben való tapasztalata is változó, amely részben a képzésből is adódik. Ugyanis a nyiroködéma-kezelést oktató alaptanfolyamok tudásanyaga széles határok között mozog, a szakmai továbbképzés ugyanakkor nem megoldott. Ezen a szakterületen az alapos tudás megszerzéséhez az alaptanfolyam elvégzése után többéves gyakorlatra van szükség. A nyiroködéma-kezelésben való jártasság az orvosok szempontjából nincs definiálva. OEP-finanszírozott ellátás nyiroködéma-ambulanciákon és pontosan nem definiált, úgynevezett nyiroködéma-centrumokban történik. Ez utóbbiak más osztályok (például krónikus belgyógyászat, bőrgyógyászat, rehabilitáció) keretein belül múködő részlegek. Szükség lenne a limfológia mint szubspecialitás elismerésére, és a honi limfológusképzés feltételrendszerének kidolgozására. Így a jelenleg alárendelt helyzetü, ugyanakkor speciális, hiánypótló feladatot ellátó részlegek valóban önálló nyiroködéma-centrumként funkcionálhatnának. A palliatív ellátásba is fontos lenne beépíteni a nyiroködéma-kezelést, hiszen nagymértékben javíthatja a beteg életminőségét, és a komplex palliatív ellátásnak alapvető része [16, 20, 27]. Az időben elkezdett kezeléssel elkerülhetők a szövődmények, az egészségügyi kiadások csökkenthetők és a beteg számára jobb életminőség biztosítható [28].

Anyagi támogatás: A közlemény megírása anyagi támogatásban nem részesült.

A cikk egy része bemutatásra került 2015-ben a Hétköznapi gyakorlat a börgyógyászatban címü konferencián és a Nyiroködéma-kongresszuson, W. E. szerzőségével. A cikk végleges változatát a szerző elolvasta és jóváhagyta.

Érdekeltségek: A szerzőnek nincsenek érdekeltségei.

\section{Köszönetnyilvánítás}

Köszönettel tartozom $d r$. Telkes Márta főorvosnőnek munkám támogatásáért. Ezt a munkát édesapámnak ajánlom szeretettel, és köszönöm, hogy az elkészült kéziratot átolvasta.

\section{Irodalom}

[1] Rönkä, R. H., Pamilo, M. S., von Smitten, K. A., et al.: Breast lymphedema after breast conserving treatment. Acta Oncol., 2004, 43(6), 551-557.

[2] Beesley, V., Janda, M., Eakin, E., et al.: Lymphedema after gynecological cancer treatment: prevalence, correlates and supportive care needs. Cancer, 2007, 109(12), 2607-2614.

[3] Tsai, R. J., Dennis, L. K., Lynch, C. F., et al.: The risk of developing arm lymphedema among breast cancer survivors: meta-analysis of treatment factors. Ann. Surg. Oncol., 2009, 16(7), 19591972.

[4] Treves, N.: An evaluation of the etiological factors of lymphedema following radical mastectomy; an analysis of 1,007 cases. Cancer, 1957, 10(3), 444-459. 
[5] Helyer, L. K., Varnic, M., Le, L. W., et al.: Obesity is a risk factor for developing postoperative lymphedema in breast cancer patients. Breast J., 2010, 16(1), 48-54.

[6] Shaw, C., Mortimer, P., Judd, P. A.: A randomized controlled trial of weight reduction as a treatment for breast cancer-related lymphedema. Cancer, 2007, 110(8), 1868-1874.

[7] Sagen, A., Kåresen, R., Risberg, M. A.: Physical activity for the affected limb and arm lymphedema after breast cancer surgery. A prospective, randomized controlled trial with two years followup. Acta Oncol., 2009, 48(8), 1102-1110.

[8] Schmitz, K. H.: Balancing lymphedema risk: exercise versus deconditioning for breast cancer survivors. Exerc. Sport Sci. Rev., 2010, 38(1), 17-24.

[9] Salati, S. A., Rather, A. A.: Carcinoma en cuirasse. J. Pakistan Assoc. Dermatol., 2013, 23(4), 452-454.

[10] Földi, E.: The treatment of lymphedema. Cancer, 1998, 83(Suppl. 12B), 2833-2834.

[11] The diagnosis and treatment of peripheral lymphedema: 2013 Consensus Document of the International Society of Lymphology. Lymphology, 2013, 46(1), 1-11.

[12] Keeley, V.: Drugs that may exacerbate and those used to treat lymphoedema. J. Lymphoedema, 2008, 3(1), 57-65.

[13] Ezzo, J., Manheimer, E., McNeely, M. L., et al.: Manual lymphatic drainage for lymphedema following breast cancer treatment. Cochrane Database Syst. Rev., 2015, (5), CD003475. doi: $10.1002 / 14651858$

[14] Daróczy, J.: Lymphedema. [Nyirokoedema.] K.u.K. Kiadó, Budapest, 2009. [Hungarian]

[15] Godette, K., Mondry, T. E., Johnstone, P. A.: Can manual treatment of lymphedema promote metastasis? J. Soc. Integr. Oncol., 2006, 4(1), 8-12.

[16] Cheville, A. J.: Lymphedema and palliative care. LymphLink, 2002, 14(1), 1-14

[17] Hsiao, P. C., Liu, J. T., Lin, C. L., et al.: Risk of breast cancer recurrence in patients receiving manual lymphatic drainage: a hospital-based cohort study. Ther. Clin. Risk Manag., 2015, 11, 349-358.

[18] Pinell, X. A., Kirkpatrick, S. H., Hawkins, K., et al.: Manipulative therapy of secondary lymphedema in the presence of locoregional tumors. Cancer, 2008, 112(4), 950-954.
[19] Weissleder, H., Schuchbardt, C.: Malignant lymphedema. In: Weissleder, H., Schuchhardt, C. (eds.): Diseases of the lymphatic system. [Erkrankungen des Lymphgefaßsystems.] Viavital Verlag, Köln, 2011. [German]

[20] Towers, A., Hodgson, P., Shay, C., et al.: Care of palliative patients with cancer-related lymphedema. J. Lymphoedema, 2010, 5(1), 72-80.

[21] Johnstone, P. A., Hawkins, K., Hood, S.: Role of patient adherence in maintenance of results after manipulative therapy for lymphedema. J. Soc. Integr. Oncol., 2006, 4(3), 125-129.

[22] Stewart, F. W., Treves, N.: Lymphangiosarcoma in post-mastectomy lymphedema. A report of six cases in elephantiasis chirurgica. Cancer, 1948, l(1), 64-81.

[23] Torres-Lacomba, M., Yuste-Sánchez, M. J., Zapico-Goñi, A., et al.: Effectiveness of early physiotherapy to prevent lymphoedema after surgery for breast cancer: randomised, single blinded, clinical trial. BMJ, 2010, 340, b5396.

[24] Mondry, T. E., Riffenburgh, R. H., Johnstone, P. A.: Prospective trial of complete decongestive therapy for upper extremity lymphedema after breast cancer therapy. Cancer J., 2004, 10(1), $42-48$.

[25] Boccardo, F., Casabona, F., De Cian, F., et al.: Lymphedema microsurgical preventive healing approach: a new technique for primary prevention of arm lymphedema after mastectomy. Ann. Surg. Oncol., 2009, 16(3), 703-708.

[26] Boccardo, F., De Cian, F., Campisi, C. C., et al.: Surgical prevention and treatment of lymphedema after lymph node dissection in patients with cutaneous melanoma. Lymphology, 2013, $46(1), 20-26$.

[27] Hewitt, B., Bugden, E., Levinson, P.: Lymphoedema management in palliative care. Cancer Forum, 2010, 34(2), 83-85.

[28] Brayton, K. M., Hirsch, A. T., O'Brien, P. J., et al.: Lymphedema prevalence and treatment benefits in cancer: impact of a therapeutic intervention on health outcomes and costs. PLoS ONE, $2014,9(12)$, el14597.

(Wenczl Enikő dr., Budapest, Nagyvárad tér 1., 1096 e-mail: ewenczl@yahoo.com)

\section{Tisztelt Szerzőink, Olvasóink!}

Az Orvosi Hetilapban megjelenő/megjelent közlemények elérhetőségére több lehetőség kínálkozik.

Rendelhető különlenyomat, melynek áráról bővebben a www.akkrt.hu honlapon (Folyóirat Szerzőknek, Különlenyomat menüpont alatt) vagy Szerkesztöségünkben tájékozódhatnak.

A közlemények megvásárolhatók pdf-formátumban is, illetve igényelhetö Optional Open Article (www.oopenart.com).

Adott dij ellenében az online közlemények bárki számára hozzáférhetök honlapunkon (a közlemények külön linket kapnak, igy más oldalról is linkelhetővé válnak).

Bővebb információ a hirdetes@akkrt.hu címen vagy különlenyomat rendelése esetén a Szerkesztőségtől kérhető. 